\title{
Molecular Identification of Cellulolytic Bacteria From Mangrove Sediment at Tin Minning Region In West Bangka
}

\section{Ardiansyah Kurniawan ${ }^{1}$, Suci Puspita Sari ${ }^{1}$, Euis Asriani ${ }^{1}$, Andi Kurniawan ${ }^{2}$, Abu Bakar Sambah $^{2} \&$ Asep Awaludin Prihanto ${ }^{2}$}

${ }^{1}$ Faculty of Agriculture, Fisheries and Biology, Bangka Belitung University, Bangka, Indonesia

${ }^{2}$ Faculty of Fisheries and Marine Science, Brawijaya University, Malang, Indonesia

\begin{abstract}
Cellulose as an abundant source of glucose in Indonesia requires acceleration of decomposition utilizing cellulolytic bacteria. Cellulolytic bacteria can be obtained from the isolation of mangrove organic matter, such as sediments. Muntok Sub-district is one of the regions with the most tin mining in West Bangka Regency also has mangroves in the coastal area. Exploration of cellulolytic bacteria in mangroves with different environmental characteristics encourages researchers to find new bacterial strains that produce cellulase enzymes with new properties. Thirteen isolates were successfully isolated from three locations. Tembelok mangrove sediments produced Seven bacterial isolates, Peltim Mangrove samples produced three isolates and from Sukal Mangrove three isolates were obtained. Seven isolates showed clear zones in the Lugol test and three isolates including were gram-positive bacteria. Molecular test with 16S rRNA analysis showed TBL1 isolate has $85 \%$ similar identity of Vibrio parahaemolyticus strain HY3 and TBL2 isolate has $98 \%$ similar identity of Bacillus amyloliquefaciens strain HS8. Bacillus amyloliquefaciens potential to further study as cellulose degrading bacteria for feed ingredients.
\end{abstract}

\section{Article History}

Received 12 April 2019

Accepted 24 June 2019

Keyword

16s rRNA,

Cellulose,

Cellulolytic Bacteria, Mangrove,

Tin Minning

\section{Introduction}

Cellulose is the most common organic polymer especially in the tropics. At the molecular level, cellulose is a linear polymer of glucose composed. It can be a problem and challenges that cellulose needs biodegradation before using an energy source of glucose. Animal feed, in addition to ruminants, can be produced with sufficient energy and economical prices through the utilization of cellulose which has been neglected so far. Cellulose as an abundant source of glucose in Indonesia requires acceleration of decomposition utilizing cellulolytic bacteria.

Cellulolytic bacteria have the ability to accelerate decomposition of organic material (Hapsoh, 2017). Andriani et al (2012) added that cellulolytic bacteria which secrete cellulase enzymes are useful as rough degradators of animal feed raw materials. Cellulolytic bacteria can be obtained from the isolation of mangrove organic matter, such as sediments 
(Kurniawan et al., 2018a; Yahya et al., 2014; Chantarasiri, 2015), leaf litter (Kurniawan et al., 2018b; Ningsih et al., 2014 ; Yulma et al., 2017) and weathered wood (Kurniawan et al., 2018c; Kurniawan et al., 2018d).

Muntok Sub-district is one of the regions with the most tin mining in West Bangka Regency (Susanto, 2015) also has mangroves in the coastal area. The tin smelting industry owned by PT. Timah is also concentrated in this area. Tin mining provides the economy and development for the people of Bangka Island but also has a negative impact on the environment (Kurniawan, 2012). The existence of cellulolytic bacteria in mangrove can be influenced by human activity in the vicinity, as Sari and Rosalina's statement (2014) that unconventional tin mining affects the success of mangrove planting. Mixing between mine waste soil can cause a decrease in physical and chemical fertility of native mangrove soil (Umroh, 2015).

It is necessary to identify cellulolytic bacteria from mangroves on Muntok sub-district to complete data on mangrove cellulolytic bacteria resources on Bangka Island. Exploration of cellulolytic bacteria in mangroves with different environmental characteristics encourages researchers to find new bacterial strains that produce cellulase enzymes with new properties. Kurniawan and Ekowati (2016) show that microorganisms have the ability to adapt to environmental changes due to heavy metal contamination and can reduce the contamination from the environment. The purpose of this study is to isolate endophytic bacteria that produce cellulase enzymes that can be used for animal feed purposes, especially in aquaculture commodities.

\section{Materials and Methods}

\section{Materials and tools}

The materials used in this study were Carboxy Methyl Cellulose (CMC), MgSO4.7H2O, $\mathrm{KNO} 3, \mathrm{~K} 2 \mathrm{HPO} 4, \mathrm{CaCl} 2.2 \mathrm{H} 2 \mathrm{O}$, yeast extract, agar, Lugol solution (2g of potassium iodine and $1 \mathrm{~g}$ iodine in $300 \mathrm{ml}$ of aquadest), and congored $0,1 \%$ solution $(0,1 \mathrm{~g}$ congored in $100 \mathrm{ml}$ aquadest). Primers for this analysis were 20F $\left(5^{\prime}-\right.$ GTAATCGTCG GCCAGTAGAGTTTGATCCTGGCTC-3') and primer reverse 1510R $\left(5^{\prime}\right.$ - CAGGAAACA GCTATGACCG GCTACCTTGTTACGACT-3').

Tools used in this research is the petri dish, incubator (Memmert, Germany), Refrigerator, PCR machine (Biorad, USA), DNA extraction kit (Promega, USA), BioEdit software, and ABIPRISM ${ }^{\circledR} 310$ Genetic Analyzer (Thermo Fisher, USA).

\section{Research Sites}

Samples of mangrove soil were taken from Sukal Mangrove, Peltim Mangrove and Tembelok Mangrove in Muntok Sub-district, West Bangka Regency, Province of Bangka Belitung Archipelago, Indonesia. Peltim mangroves are the closest mangrove to the tin smelting industry, Sukal mangroves represent coastal areas that are used for shellfish cultivation, and Tembelok becomes mangroves that have high density and far distance from human activities. Location of sampling of mangrove soil is shown in Figure 1. Bacterial isolation and screening were done in the fisheries microbiology laboratory of Brawijaya University, while DNA isolation was carried out in the Genetics laboratory of Maulana Malik Ibrahim State Islamic University, Malang. 


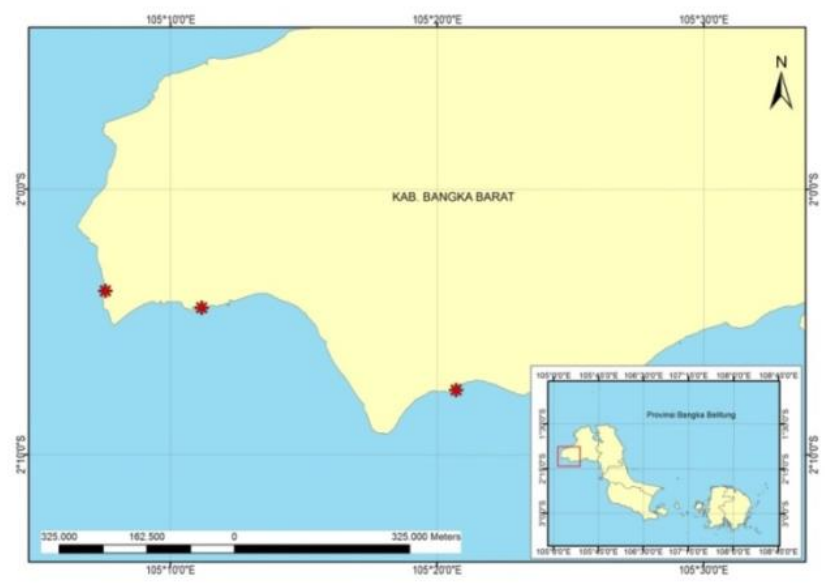

Figure 1. Soil sampling location in West Bangka, Province of Bangka Belitung Archipelago

\section{Isolation of Cellulolytic Bacteria}

Soil sampling is done with a depth of $10-20 \mathrm{~cm}$. All sample stored in the sterile container. Each sampling location was taken 2 samples and composite into a combined sample. Mangrove soil samples were weighed as much as $1 \mathrm{~g}$ and diluted to $10^{-7}$ dilutions. The resulting of dilution were grown on 1\% CMC (Carboxy Methyl Cellulose) enriched medium with a pour plate method and incubated in the incubator for 48 to 72 hours at $30^{\circ}-37^{\circ} \mathrm{C}$ temperature. The cultivation results were isolated with the same medium to obtain the pure isolate using to scratch plate method.

\section{Screening of Cellulolytic Bacteria}

Selection of cellulolytic bacteria was done by the cellulose hydrolysis test method. Pure bacterial isolates were recycled on Carboxy Methyl Cellulose enriched agar medium (CMC) by a streak method. One loop of bacteria is scratched on the medium by forming a line of approximately $1 \mathrm{~cm}$. The culture was incubated at 72 hours at $30^{\circ} \mathrm{C}$. Qualitative test uses Lugol methods. Lugol and congored solution is dripped to cover the entire medium and is allowed to stand for a minute. The clear zone formed around bacterial colonies was observed and identified as isolating of cellulose-degrading bacteria. Isolates identified to have cellulolytic activity were selected for further identification. Isolates showing the largest clear zone and positive grams were identified by sequencing DNA analysis.

\section{Molecular Identification}

The protocol for the identification of best producer of cellulose, the methods by Prihanto et al., (2016) was used with slight modification. DNA isolation was performed using the procedure of the DNA Isolation Kit (Wizard of Genomic DNA Purification Kit from Promega). The initial stage of 16S-rRNA analysis was done by isolating genomic DNA from selected bacteria then followed by amplification using PCR technique. DNA sample which was isolated as much as $2 \mu \mathrm{L}$ was dissolved in the mixture containing $6 \mu \mathrm{lddH} 2 \mathrm{O}, 10 \mu \mathrm{l} \mathrm{PCR}$ kit GoTaq $^{\circledR}$ Green Master Mix (10 x Taq polymerase buffer, dNTP, MgCl2, primer, Taq DNA polymerase, ddH2O), $1 \mu$ forward primer, and primary reverse $1 \mu \mathrm{l}$. Mixture it is then inserted into the PCR machine.

The amplification process was conditioned at a pre-denaturation temperature of 95 ${ }^{\circ} \mathrm{C}$ for 5 minutes $1 \mathrm{cycle}$ and denaturation with $30 \mathrm{cycles}$ at $95^{\circ} \mathrm{C}$ for 30 seconds, $\left(33^{\circ} \mathrm{C}, 31.5^{\circ} \mathrm{C}\right.$ and $30^{\circ} \mathrm{C}$ ) for 30 seconds, and $72^{\circ} \mathrm{C}$ for 30 seconds, continued with 1 extension cycle at $72^{\circ} \mathrm{C}$ 
for 10 minutes and $4^{\circ} \mathrm{C}$ for 5 minutes. The PCR results of all amplified DNA samples were confirmed using horizontal electrophoresis of $0,8 \%$ agarose gel. DNA bands that form later compared to markers.

The next step is purification PCR results using DNA fagment extraction kit. PCR results that have been purified added with solution special buffer, $\mathrm{Hi}-\mathrm{Di}^{\mathrm{TM}}$ Formamide (Genetic

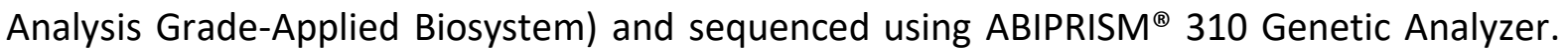
DNA sequencing uses the services of PT. Genetika Science Indonesia.

Sequencing results used to find out similarities DNA sequences with bacterial DNA sequences others in GenBank use help with the Basic Local Alignment Search program Tool (BLAST) on the site http: //www.ncbi.nlm.nih.gov. Bacterial kinship is presented in the shape of the phylogenetic tree image created with the help of fr Phylogeny programs. This program is available on the site http: // www.phylogeny.fr.

\section{Results and Discussion}

The results of the analysis show that cellulolytic bacteria can be isolated from the third sediment sample of mangrove sites. Thirteen isolates were successfully isolated from three locations. Tembelok mangrove sediments produced Seven bacterial isolates (TBL1, TBL2, TBL3, TBL3.7, TBL2.6, TBL1.6, TBL1.5), Peltim Mangrove samples produced three isolates (PTL1.6, PTL7, PTL5) and from Sukal Mangrove three isolates were obtained (SKL1.6, SKL1.5, SKL1.7). The ability to grow bacteria on media with $1 \%$ CMC means that thirteen isolates have the ability to utilize cellulase, as Huang (2012) stated that cellulolytic bacteria are able to live by degrading cellulase.

Hydrolysis using Lugol can ensure that bacterial isolates have the ability to cellulose degradation. The results of qualitative analysis using Lugol are presented in Figure 2 and Table 1. There were seven isolates that showed clear zones in the Lugol test with three isolates including gram-positive bacteria.
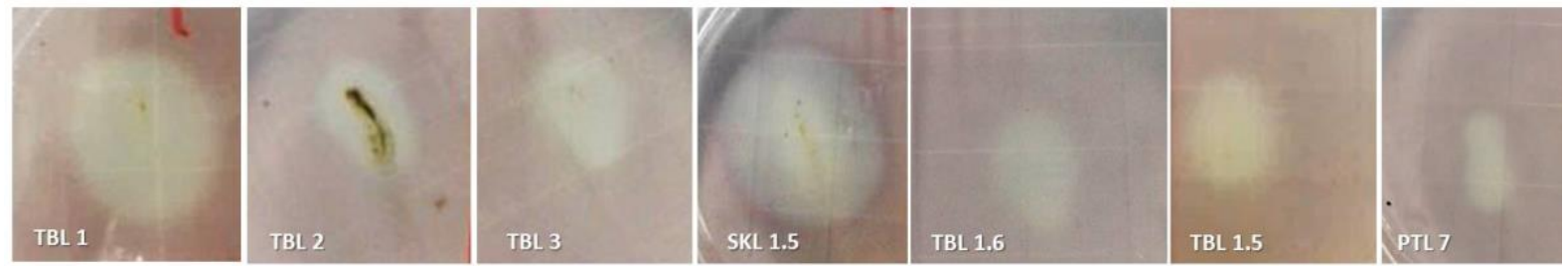

Figure 2. Qualitative test results of cellulolytic bacteria using lugol method.

Table 1. Results of Qualitative Tests for Cellulolytic Bacteria with Lugol and Congored.

\begin{tabular}{|c|c|c|c|c|}
\hline \multirow{2}{*}{ Code } & \multirow[t]{2}{*}{ Isolate } & \multicolumn{2}{|c|}{$\begin{array}{l}\text { Diameter of the clear } \\
\text { zone }(\mathrm{mm})\end{array}$} & \multirow{2}{*}{$\begin{array}{l}\text { Gram } \\
\text { staining }\end{array}$} \\
\hline & & Lugol & Congored & \\
\hline & TBL1 & 15 & 1 & Positive \\
\hline & TBL2 & 6 & 5 & Positive \\
\hline & TBL3 & 9 & 0 & Negative \\
\hline & TBL3.7 & 0 & 0 & - \\
\hline & TBL2.6 & 0 & 0 & - \\
\hline & PTL1.6 & 0 & 0 & - \\
\hline & SKL1.6 & 0 & 0 & - \\
\hline & TBL1.6 & 7 & 0 & Negative \\
\hline
\end{tabular}




\begin{tabular}{llll} 
SKL1.5 & 13 & 5 & Positive \\
SKL1.7 & 0 & 0 & - \\
TBL1.5 & 8 & 1 & Negative \\
PTL7 & 5 & 1 & Negative \\
PTL5 & 0 & 0 & - \\
\hline
\end{tabular}

Cellulolytic bacterial identified in Tembelok mangroves were more number of isolates than other mangrove samples, possibly related to the density and utilization of the mangrove environment. The density of Tembelok mangrove trees is still high with various types of mangroves associated, while the mangrove Sukal and Peltim are Avicennia marina homogeneous species with low density. Among the different environments, the sediments of mangrove forests are suitable for exploring cellulose-degrading microorganisms because of continuous input of cellulosic carbon in the form of litter which then acts as a substrate for decomposition by microbe (Behera et al., 2017). The higher density of mangroves has a positive impact on the addition of the number of mangrove leaf litter and reduce the number of Vibrio sp bacteria colonies (Arta et al., 2009).

Tembelok mangroves include mangroves with minimal human activity around them, while the coastal areas around the mangrove Sukal are used for cultivation of blood clams and Peltim Mangroves adjacent to the tin smelting industry. Rigonato (2017) shows that pristine mangroves have a pronounced effect on microbial community composition and contaminated mangroves that have different microbial communities at different times. Chemical pollution, particularly accumulation and bio-transformation of toxic metals could be a significant factor for reduction of mangrove biodiversity (Maiti and Chowdhury, 2013).

The results of molecular test with 16S rRNA analysis are the TBL1 isolate has $85 \%$ similar identity of Vibrio parahaemolyticus strain HY3 and isolate TBL2 has 98\% similar identity of Bacillus amyloliquefaciens strain HS8. Hence, we named this isolate as Vibrio parahaemolyticus_UBB_TBL1 and Bacillus amyloliquefaciens_UBB_TBL2. Phylogenetic tree of this isolate was depicted in figure 3.

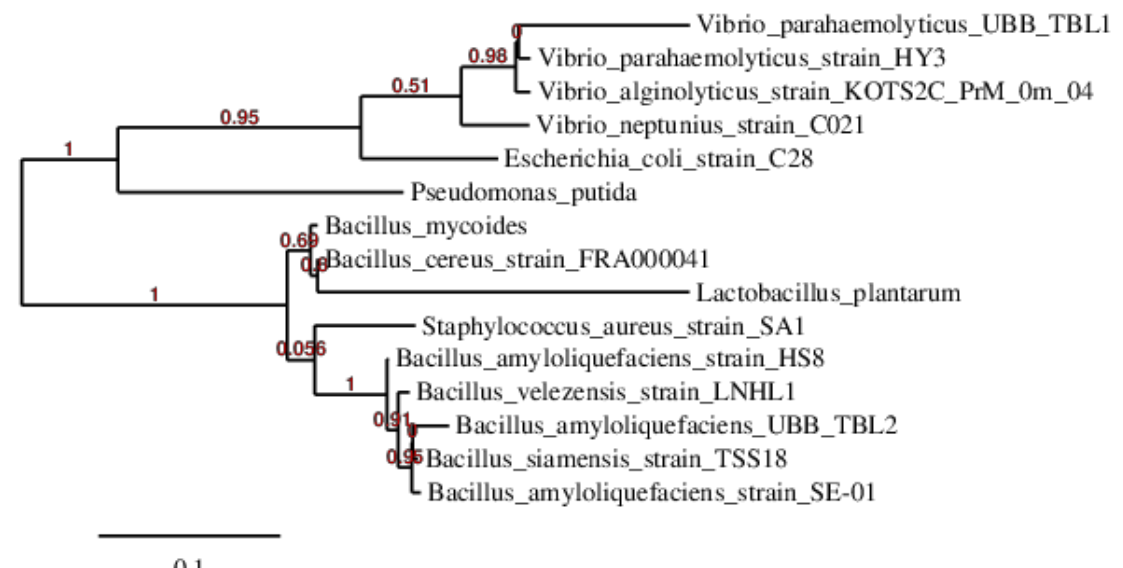

Figure 3. Phylogenetic Tree of bacterial isolates

The results of the analysis of genetic joining phylogenetic trees (neighbor joining) can be seen in Figure 3. The numbers contained in each tree branch show the bootstrap value. Based on phylogenetic trees which included several GenBank sequence data as a comparison, it showed that Vibrio parahaemolyticus_UBB_TBL1 bacteria were in the same branch and 
node (genus) as Vibrio parahaemolyticus strain HY3 with boostrap value of 0 and Bacillus amyloliquefaciens_UBB_TBL2 with Bacillus amyloliquefaciens strain HS8 with boostrap value of 0.96 .

Vibrio parahaemolyticus is a Gram-negative halophilic bacterium that is found in estuarine, marine and coastal environments and pathogenic bacterium for humans (Letchumanan et al, 2014). This bacterium is also found in shrimp from the north coast of Java (Shobharani et al, 2013). Gao et al. (2011) reported a cellulolytic bacterium from Vibrio genus isolated from mangrove soil in Xiamen, Fujian province of China.

Bacillus amyloliquefaciens is also identified at the mangrove forests of Andaman and Nicobar islands (Geetha et al., 2011) and Kraton Mangrove, Pasuruan, East Java (Yahya et al., 2014). Bacillus amyloliquefaciens obtained from cassava yeast tape has the ability to degrade flour substrates cassava, rice bran and carboxymethylcellulose (Soeka et al., 2015). The potential of Bacillus amyloliquefaciens as cellulose degrading bacteria for feed ingredients can be studied further.

\section{Conclusions}

Thirteen isolates were successfully isolated from three locations. Tembelok mangrove sediments produced Seven bacterial isolates, Peltim Mangrove samples produced three isolates and from Sukal Mangrove three isolates were obtained. Seven isolates showed clear zones in the Lugol test and three isolates including were gram-positive bacteria. Molecular test with 16S rRNA analysis showed TBL1 isolate has $85 \%$ similar identity of Vibrio parahaemolyticus strain $\mathrm{HY} 3$ and TBL2 isolate has $98 \%$ similar identity of Bacillus amyloliquefaciens strain HS8. Bacillus amyloliquefaciens potential to further study as cellulose degrading bacteria for feed ingredients.

\section{Acknowledgment}

The authors were grateful to the Directorate General of Research and Technology Research and Development at the Ministry of Research, Technology and Higher Education for financially supported at University Cooperation Research between Bangka Belitung University and Brawijaya University in 2017-2018.

\section{References}

Andriani, Y., Sastrawibawa, S., Safitri, R. \& Abun. 2012. Isolation and Identification of Cellulolytic Microbes as Biodegradators Rough Fiber in Feed Materials from Agricultural Waste. IJAS. 2 (3).

Arta, A.P, Maidie, A. \& Saptiani, G. 2009. The Effect Of Mangrove Vegetation Treatment On Vibrio Sp Bacterial Population In Bontang Coast. Jurnal Kehutanan Tropika Humida. 2 (2): 133-142.

Behera, B.C., Sethi, B.K., Mishra, R.R., Dutta, S.K. \& Thatoi, H.N. 2017. Microbial cellulases Diversity \& biotechnology with reference to mangrove environment: A review. Journal of Genetic Engineering and Biotechnology. 15 : 197-210.

Chantarasiri, A. 2015. Aquatic Bacillus cereus JD0404 isolated from the muddy sediments of mangrove swamps in Thailand and characterization of its cellulolytic activity. Egypt J Aquat Res. 41(3):257-64. 
Gao, Z.M., Xiao, J., Wang, X.N., Ruan, L.W., Chen, X.L. \& Zhang, Y.Z. 2011. Int. J. Syst. Evol. Microbiol. 62: 1958-1962.

Geetha, I., Manonmani, A.M. \& Prabakaran, G. 2011. Bacillus amyloliquefaciens: A mosquitocidal bacterium from mangrove forests of Andaman \& Nicobar islands, India. Acta Tropica. 120. (3): 155-159.

Hapsoh, Wawan, Dini, I.R. \& Siregar, J.A.. 2017. Compatibility Tests of Potential Cellulolytic Bacteria and Growth Optimization in Several Organic Materials. International Journal of Science and Applied Technology. 2 (2).

Kurniawan, A., Sari, S.P., Asriani, E., Kurniawan, A., Sambah, A.B. \& Prihanto, A.W. 2018b. Mangrove Leaf Litter Cellulolytic Bacteria on Bangka Island. Samakia. 9 (1).

Kurniawan, A., Sari, S.P., Asriani, E., Kurniawan, A., Sambah, A.B. \& Prihanto, A.W. 2018c. Isolation and Identification of Cellulose Degradation Bacteria from Tukak Sadai Mangrove Ecosystem, South Bangka. Jurnal Perikanan Pantura. Vol. 1. No.2

Kurniawan, A., Sari, S.P., Asriani, E., Kurniawan, A., Sambah, A.B. \& Prihanto, A.W. 2018d. Cellulolytic Bacteria in Weathered Wood in Sungailiat Mangrove, Bangka Dan Tukak Sadai, South Bangka. Proceedings of the National Wetland Environment Seminar. 3 (1): 301-305.

Kurniawan, A., Sari, S.P., Asriani, E., Kurniawan, A., Sambah, A.B. \& Prihanto, A.W. 2018a. Isolation and Identification of cellulolytic bacteria from mangrove sediment in Bangka Island. IOP Conf. Series: Earth and Environmental Science 137.

Kurniawan, A. 2012. Introduction To Post-Tin Mining Aquaculture. UBB Press.

Kurniawan. A, and N. Ekowati, 2016. Mycoremediation of Heavy Metal: A Review. Bioteknologi \& Biosains Indonesia. 3 (1) : 36-45.

Letchumanan. V, Chan, K.G. \& Lee, L.H. 2014. Vibrio parahaemolyticus: A Review on the Pathogenesis, Prevalence and Advance Molecular Identification Techniques. Frontiers in microbiology. 5 (705)

Maiti, S.K \& Chowdhury, A. 2013. Effects of Anthropogenic Pollution on Mangrove Biodiversity: A Review. Journal of Environmental Protection. 4 : 1428-1434.

Ningsih, R.L., Khotimah, S. \& Lovadi, I. 2014. Cellulose Degradation Bacteria from Avicennia alba Blume Leaf Litter in the Safety Mangrove Forest in Pontianak Regency. Protobiont. 3 (1): $34-40$

Prihanto, A.A, \& Wakayama, M. 2016. Adv. Food Nutr. Res. 79 1-25.

Rigonato, J. 2017. Temporal assessment of microbial communities in soils of two contrasting mangroves. Braz J Microbiol. http://dx.doi.org/10.1016/j.bjm.2017.04.008

Sari, S. P. \& Rosalina, D. 2014. Success Rate of Mangrove Planting in Post-Mining Land in South Bangka Regency. Maspari Journal. 6 (2).

Shobharani, P., Yogesh, D., Halami. P.M. \& Sachindra. N.M. 2013. Potential of Cellulase From Bacillus megaterium for Hydrolysis of Sargassum. Journal of Aquatic Food Product Technology. 22 (5). 520-535.

Soeka,Y.S., Rahmansyah, M. \& Sulistiani. 2015. Optimization of a-Amylase Enzyme from Bacillus amyloliquefaciens 01 which are Induced by Rice Bran and 
Carboxymethylcellulose. Jurnal Biologi. 11 (2) : 259-266.

Susanto. 2015. Tin-Bottom Areas in Bangka Belitung with Spot_6 Satellite Data. National Seminar on Science and Technology 2015. Faculty of Engineering, Muhammadiyah University, Jakarta.

Umroh. 2015. Seeding and Planting Rhizophora apiculata in post-conventional tin mining (TI) areas in Muara Kudai, Bangka Regency.Jurnal Kelautan. 8 (1).

Yahya, Happy, N., Yenny, R. \& Soemarno. 2014. Characteristic of extracelluler metabolic of coastal ecosystem bacteria producing histidine decarboxylase crude. International Food Research Journal. 21 (4) : 1337-1347

Yulma, Ihsan, B., Sunarti, Malasari, E., Wahyuni, N. \& Mursyban. 2017. Identification of Bacteria in Decomposed Mangrove Leaf Litter in Mangrove and Proboscis Conservation Areas in Tarakan City. Journal of Tropical Biodiversity and Biotechnology. 2. 28-33. 